\title{
Estudio de la adición de arcillas calcinadas en la durabilidad de hormigones
}

\section{Study of the addition of calcined clays in the durability of concrete}

\author{
Rancés Castillo Lara*1, Mathieu Antoni**, Adrián Alujas Díaz*, Karen Scrivener**, José Fernando Martirena Hernández* \\ * Universidad Central de Las Villas, Santa Clara, Cuba \\ ** Escuela Politécnica Federal de Lausana (EPFL), SUIZA \\ Fecha de recepción: 21/07/ 2010 \\ Fecha de aceptación: 30/ 09/2010 \\ PAG. 25 - 40 \\ Resumen
}

Actualmente son bien conocidas las ventajas económicas y medioambientales de la sustitución del clínker de cemento por otros materiales cementicios suplementarios. Las arcillas calcinadas en forma de metacaolín han recibido por ejemplo especial atención en años recientes. Se conoce que estas adiciones, cuando se añaden a morteros y hormigones, mejoran tanto su resistencia mecánica como su durabilidad. El objetivo de este trabajo es evaluar el comportamiento de las propiedades físico-mecánicas y la durabilidad en microhormigones, empleando arcillas calcinadas y molidas como material sustituyente del $30 \%$ en peso del cemento Pórtland ordinario (CPO). Para ello se utilizó una tierra arcillosa, compuesta principalmente por mineral caolín de bajo grado de pureza, para la obtención de arcillas calcinadas como minerales cementicios suplementarios. Los mejores resultados se resistencia a la compresión a los 28 días se obtuvieron para la arcilla sedimentada y calcinada, la cual posee mayor contenido de mineral caolín debido a un proceso de purificación por sedimentación de la materia prima acometido sólo para esta adición. Sin embargo, los ensayos de absorción de agua por capilaridad arrojaron los mejores resultados para el suelo arcilloso calcinado, el cual posee una elevada finura en comparación al resto de los materiales estudiados. Los menores valores mostrados por esta adición, tanto de porosidad capilar como de sorptividad, indican que existió un predominio del fenómeno de la compacidad e impermeabilidad, lograda en la matriz cementicia al usar un material tan fino, por encima del efecto de la reacción puzolánica. Estudios en la microestructura del gel de C-S-H, usando energía dispersiva por rayos-X (EDX), demostraron como el empleo de arcillas calcinadas en sustitución del CPO favorece la formación de productos de hidratación más estables, principalmente monosulfos del tipo hemicarbo y monocarbo, lo cual es conveniente para el hormigón ante la posible acción de diferentes mecanismos de degradación.

Palabras Clave: Arcillas calcinadas, durabilidad, absorción capilar, porosidad, productos de hidratación

Abstract

Currently economical and environmental advantages of cement clinker replacement by other supplementary cementious materials are well known. For example calcined clays, such as metakaolin, have drawn special attention during recent years. It is well known that these admixtures added to mortars and concretes improve mechanical strength as well as durability. The purpose of this study is to evaluate the behavior of physical-mechanical properties and durability in micro-concretes, by employing calcinated and grinded clays as replacement material, by $30 \%$ of ordinary Portland cement (O PC). Therefore, clay soil was employed, which is mainly composed by low-purity-kaolin mineral, so as to obtain calcined clays to be used as supplementary cementious minerals. Best results for compressive strength at 28 days were obtained by sedimentary calcined clays, which have higher content of kaolin mineral thanks to a purification process by means of raw material sedimentation conducted on this admixture only. Nevertheless, capillary water absorption tests delivered best results for calcined clay soil, which finesse is quite high. Lower values showed by this admixture, as much for capillary porosity and sorptivity, revealed there was a predominance of compaction and impermeability phenomena achieved by cementious matrix using such fine material, over the effect of puzzolanic reaction. M icro-structure studies on C-S-H gel, employing energy dispersive x-ray (EDX) technique, demonstrated that the use of calcined clays as replacement of RPC favors the creation of quite stable hydration products, mainly monosulfos of hemicabo and monocarbo types, which is convenient for concrete against possible deterioration actions from different mechanisms.

Keywords: Calcined clays, durability, capillary absorption, porosity, hydration products

\section{Introduction}

Concrete durability has recently become the focus point for several authors and specialists all over the world.

\footnotetext{
1 Autor de correspondencia / Corresponding author:

E-mail: rancesc@uclv.edu.cu
} 
In particular the case of Cuba, which is an island having buildings near marine environment, it is quite important to study durability behavior of this material against different external aggressive agents.

Cuban regulation NC 250-2005 “Durability requirements for design and construction of structural concrete buildings and civil works" defines durability as concrete ability to endure physical and chemical exposure conditions during operational life it has been designed for.

There are several factors affecting concrete durability properties. From internal point of view, those are composition and distribution of components and raw materials as well as structural design characteristics themselves. Among material external features, exposure degree and environmental aggressive conditions are also relevant for durability.

Water, besides covering $71 \%$ of earth's crust and being the most used material by mankind, may be regarded as the fundamental reason for construction materials deterioration, especially concrete. Excess of water contained by concrete, expressed as high watercement ratio, damages material quality. As a consequence of bleeding phenomenon, the presence of pore capillarity increases, mainly those connected to the exterior zone; furthermore the volume of water occluded in concrete mass increases, later turns into big pores inside the material. Such high porosity level, besides affecting concrete physical-mechanical properties, also affects impermeability and consequently its protection against external environmental actions, thus decreasing durability. The most permeable concrete is, the easiest access penetration of aggressive chemical substances will be, such as chloride ions and sulfates. All of them need a transportation means to reach the inner concrete mass, and water is the element that generally facilitates such work.

Studying fluids and substances transportation mechanisms inside and towards material is a common practice to assess durability properties on materials. It has been demonstrated that humidity content gradients, hydrostatic pressure, loads and chemical concentrations affect fluid equilibrium state in a porous material therefore; liquid transportation takes place in order to re-establish such equilibrium. 
Such fluid transportation process is generally described in terms of adsorption, diffusion, permeability and absorption. In concrete, physical structure (distribution and pores size) as well as water condition inside these pores, influence the transportation process (M uhammed Basheer, 2001).

The most relevant efforts are oriented to obtain material performances, so that it can be able to endure different damage mechanisms it will be exposed to. In that sense, the use of active mineral admixtures in concrete fabrication has proven to be a feasible and effective alternative to increase durability properties of such material. It basically occurs because of increased content of reactive products, favored by the additional generation of hydrates in the puzzolanic reaction, which enables lower capillary porosity and, therefore, higher strength and durability (Agarwal, 2006, Lawrence et al., 2005, Papadakis and Tsimas, 2002, M ehta and M onteiro, 2001).

Among puzzolans used for cement and concrete mixtures, in the search of improving durability properties, metakaolin is found. There have been several studies assessing its great contribution when used as replacement material for ordinary Portland cement. It has been demonstrated that metakaolin accelerates Portland cement hydration and decreases calcium hydroxide presence in mixtures, improving permeability and therefore, reducing ion chloride penetration in concretes exposed to seawater contact, also increasing resistance against sulfate attacks. Furthermore, mixtures elaborated from such admixture show lower porosity, water absorption and sorptivity values (Bai et al., 2003, Al-Akhras, 2006, Justice, 2005, Talero, 2005, Sabir et al., 2001, Gonçalves et al., 2009).

The inconveniences of metakaolin employment are based on the requirement of pure kaolin mineral content and high energetic costs involved in production process. Some feasible ways to decrease such inconveniences would be the employment of clays with lower purity degree, together with an effective energetic production process during calcination. The current study considers a low purity degree of kaolin mineral in clay soil as raw material. A previous study demonstrated that calcined clays from clay soil had quite good puzzolanic properties when employed as replacement of ordinary Portland cement in mixtures and mortars. 
The purpose of the current research is to assess the behavior of physical-chemical properties and durability on microconcretes elaborated from calcinated clays as substitute replacement of ordinary Portland cement. Studies were developed on two scales. At macro-structural level, compressive strength and water absorption were determined by means of the corresponding basic parameters of effective porosity (water mass required to saturate material) and sorptivity (penetration extent). While, at micro-structural level, the contribution to more stable hydration products was determined by means energy dispersive $\mathrm{x}$-ray technique.

\section{Materials and experimental methods}

\subsection{Raw materials}

Micro-structure tests were conducted at Construction Materials Laboratory (LMC), EPFLSwitzerland. While studies developed to asses macrostructures were conducted at the Research and Development Center for Structures and Materials (CIDEM), UCLV - Cuba. Cuban P350 cement was employed to elaborate samples, classified as type I, according to American regulation ASTM C150-02 having a compressive strength of $35 \mathrm{MPa}$ at 28 days. Table 1 shows a summary of its chemical composition and some physical features.

Two kinds of calcined clays were basically studied. Admixture named T-120 is composed of clay soil, while sedimentary clay, from such soil sedimentation, was named AS-900.The elaboration of such materials consisted in a calcination process at $900{ }^{\circ} \mathrm{C}$ for 1 hour, under controlled temperature conditions in a laboratory furnace and, then they were grinded during 120 minutes by a ball mill of 600 liters capacity.

Clay soil was employed as raw material for both admixtures elaboration, from national mountain range, which is commonly used for the production of bricks and ceramic blocks. This admixture is characterized as a mineral clay admixture, basically kaolinite and montmorillonite, all of them with low purity degree (Fernandez, 2009).

So as to assess the contribution of active mineral admixtures, a set containing the same amount of cement was introduced by replacing cement by calcareous filler (F). 
Such material was grinded during 60 minutes to achieve lower fineness than cement's and similar to the other admixtures. Table 1 also indicates physical and chemical properties of used admixtures.

Tabla 1. Composición química y propiedades físicas del cemento y adiciones utilizadas Table 1. Chemical composition and physical properties of employed cements and admixtures

\begin{tabular}{||c|c|c|c|c||}
\hline Propiedades/Properties & $\mathrm{CPO}$ & $\mathrm{T} 120$ & $\mathrm{AS}-900$ & $\mathrm{~F}$ \\
\hline $\mathrm{SiO}_{2}$ & 22,034 & 57.74 & 43.89 & 0.20 \\
\hline $\mathrm{Al}_{2} \mathrm{O}_{3}$ & 4,85 & 18.71 & 24.73 & 0.50 \\
\hline $\mathrm{Fe}_{2} \mathrm{O}_{3}$ & 3,23 & 7.07 & 11.13 & 0.13 \\
\hline $\mathrm{CaO}$ & 60,58 & 1.85 & 1.38 & 54.78 \\
\hline $\mathrm{MgO}$ & 1,65 & 1.80 & 2.63 & 0.27 \\
\hline $\mathrm{SO}_{3}$ & 3,22 & 0.02 & 0.08 & 0.1 \\
\hline $\mathrm{K}_{2} \mathrm{O}$ & 0,621 & 0.65 & 1.10 & 0.10 \\
\hline $\mathrm{MnO}_{\mathrm{Na}} \mathrm{O}$ & 0,075 & 0.12 & 0.14 & 0.01 \\
\hline $\mathrm{PPI}$ & 0,303 & 2.68 & 1.99 & 0.10 \\
\hline Álcalis/Alkalis \% $\left(\mathrm{Na}_{2} \mathrm{O}\right)$ eq & 3.31 & 8.57 & 9.81 & 43.00 \\
\hline Superficie específica/Specific surface $\left(\mathrm{m}^{2} / \mathrm{g}\right)$ & 0,71 & 3.11 & 2.70 & 0.17 \\
\hline Densidad/Density $\left(\mathrm{g} / \mathrm{cm}^{3}\right)$ & 1.11 & 7.05 & 5.19 & 1.09 \\
\hline Tamaño medio de grano/Average grain size $(\mu \mathrm{m})$ & 25.45 & 3.83 & 7.47 & 10.42 \\
\hline \hline
\end{tabular}

Figure 1 shows a comparison between cement and admixtures granulometry curves used in this study, obtained by means of laser granulometry technique. It can be seen that employed cement is the thickest material, having $25.45 \mu \mathrm{m}$ average particle sizes. All admixtures grinded by such conducted treatment show lower fineness values compared to concrete.

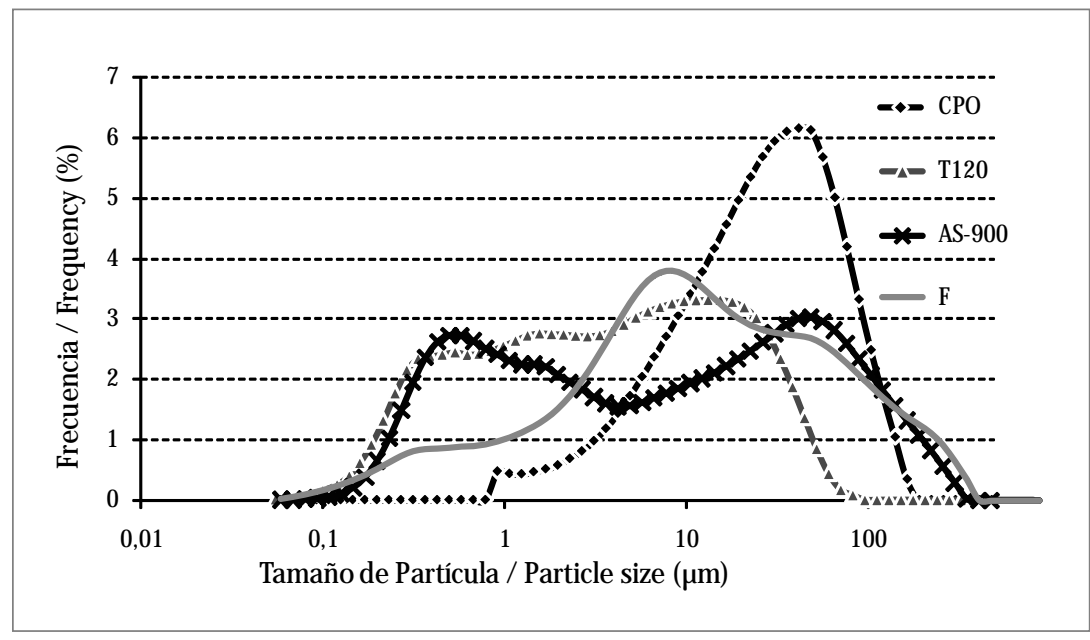

Figura 1. Distribución de tamaño de partícula de las materias primas Figure 1. Distribution of particles sizes from raw materials 


\subsection{Experimental M ethod}

The current study was divided into the following experimental phases.

Phase 1. Sedimentation and calcination process on clay soil and sedimentary clay

Clay soil under natural condition was exposed to sedimentation process thus obtaining a purified clay material. Sodium silicate was employed as deflocculate agent with a concentration of $0.02 \%$, which helped to achieve the lowest possible grain sizes and contributed to the effectiveness of such process. Calcination was conducted in a laboratory muffle, where materials were placed on ceramic pots at temperature and residence time of $900{ }^{\circ} \mathrm{C}$ and 1 hour, respectively.

Phase 2: Activation by means of grinding treatment on calcined clays, sugar crane straw and calcareous filler.

Phase 3: Application and study in micro-concretes Micro-concrete samples were elaborated of $40 \times 40 \times 160 \mathrm{~mm}$, in accordance with requirements by Cuban regulation N C 54-207, by replacing $30 \%$ of cement by admixtures. O rdinary Portland cement was employed with calcareous aggregate, both commonly used by construction industry in Cuba. A liquid chemical super plasticizer water reducer additive was employed at $1 \%$ of total binder agent weight, which allowed the reduction of water/binder ratio to 0.4 . Artificial sand obtained from limestone crushing process was employed as aggregate. Limestone was sieved to settle three portions, combined in such a way the air space percentage will be effectively covered by cementious paste. The thick portion (2.5-5.0 $\mathrm{mm}$ ) represented $50 \%$ of total aggregate weight, while medium-size portion $(0.5-2.5 \mathrm{~mm})$ and fine portion (0$0.5 \mathrm{~mm}$ ) corresponded to $25 \%$, respectively. These samples were tested to determine compressive strength at 1, 7 and 28 days. Results are shown in Figure 2 .

The effect of puzzolans over concrete durability was evaluated by means of a comparison among different mixtures, containing and not containing admixtures. Water absorption test results were obtained in accordance with Cuban regulation NC 345:2005 "Hardened concrete - Determination of water absorption by means of capillarity". 
The samples to be tested were obtained by dividing a $40 \times 40 \times 160 \mathrm{~mm}$ specimen into 20 to 30 thickness sheets. Consequently, such sheets were previously protected under equilibrium moisture, which was achieved with a drying period of 48 hours at $50 \stackrel{\circ}{ } \mathrm{C}$ until reaching constant weight. Afterwards sheets were cooled at environmental temperature, samples' side areas were covered with paraffin and, at this moment their initial weight was determined (completely dried). Later they were placed on a fine sand bed, not higher than 10 $\mathrm{mm}$ thickness, in a sealed container with water coverage of approximately $5 \mathrm{~mm}$ over sand bed and; liquid penetration time was measured by means of weight differences. M easurement intervals were of $5,10,15,30$ minutes; 1, 2, 3, 4, 6 hours; 1, 3, 5, y 7 days from test beginning date. All micro-concrete samples were evaluated at 1, 7 and 28 days from material elaboration date. So as to obtain capillary water absorption results, average values were taken from measurements conducted on 5 specimens for each mixture at each given age, which are depicted in Figure 4. In the case of sorptivity, the 10 first water absorption values on each curve were considered for calculation, and an average was calculated on results obtained by 5 specimens for each sample at each age. Such results are indicated in Figure 6. Sorptivity was obtained for each sample and test age, in accordance with the following expression:

$i=S \sqrt{t}$

i: volumen de agua absorbido por unidad de sección transversal $(\mathrm{mm})$ ó $\left(\mathrm{mm}^{3} / \mathrm{mm}^{2}\right) /$

Volume of absorbed water per transverse section unit $(\mathrm{mm})$ or $\left(\mathrm{mm}^{3} / \mathrm{mm}^{2}\right)$

S: sorptividad/sorptivity ( $\mathrm{mm} / \mathrm{vs}$ )

t: tiempo/time (s)

Capillary porosity was determined by comparing percentage of completely dry mass on tested samples with their saturated weight values without surface moisture. After samples completed capillary test at 7 days, they were submerged during 48 hours under a water container, then their weight values were measured in normal air conditions without surface moisture. Results are indicated in Figure 5.

In order to assess the influence of calcined clays on micro-concretes regarding cement moisture at micro-structural scale, an energy dispersive $x$-ray (EDX) test was conducted by means of a scanner electronic microscopy (SEM). 
Such technique enabled the determination of atomic relations for internal and external C-S-H, thus allowing a comparison on chemical compositions of similar hydrates in different cementious systems and therefore to determine hydrated and non-hydrated phases on studied samples. To conduct such determination, micro-cement specimens were sliced, and they were soaked with resin to mold polished sections. Basically the purest clay system (AS900) was compared to ordinary Portland cement (OPC) at 28 days, for internal and external C-S-H (Figures 8 and 9 , respectively).

\section{Results and Discussion}

\subsection{Analysis of micro-concretes results}

Authors of the current study decided to develop a ratio scaling and evaluation on micro-concretes, in order to reach a practical application of results obtained from previous researches on pastes and mortars. Such information would serve as premise for the use of available technologies employing this type of mixture. Microconcrete is a structural mortar which is elaborated with aggregates of different granulometry: fine, coarse, medium at a reduced scale, where aggregate size does not exceed 10 or $12 \mathrm{~mm}$, in some cases it can even be smaller, depending on the product it will be used for.

\section{Compressive strength}

Figure 2 shows the results on compressive strength test for samples elaborated from micro-concrete. All values at 28 days were higher than $45 \mathrm{MPa}$ and AS900 system reached the highest value, approximately 80 $\mathrm{MPa}$, which agrees with previous results obtained from mortars. The graph shows the trend of calcined clay soil (T-120) to increase its values at older ages, which might possibly exceed pure Portland values. Higher compressive strength values may be explained by puzzolanic reaction developed by these admixtures, together with higher compaction effect granted to cementious matrix, due to its high fineness. 
In order to compare calcined clays behavior in mortars and micro-concretes, compressive strength values were percentually expressed (Figure 3 ) in relation to values obtained by the corresponding filler for each case (dashed line). It is important to highlight that microconcrete values (MC) are in accordance with values obtained by mortars (see Figure 3), being sedimentary calcined clay (AS-900) the most reactive material of all. Besides, at early ages (1d), compressive strengths - higher than reference mixture with the same cement content (Filler system) - can be observed in micro-concretes with $30 \%$ of cement replacement by puzzolans. Above indicates the potential use of such materials as active mineral admixtures in replacement of cement - not considerably affecting requirements - for technological processes as far as compression is concerned at early ages.

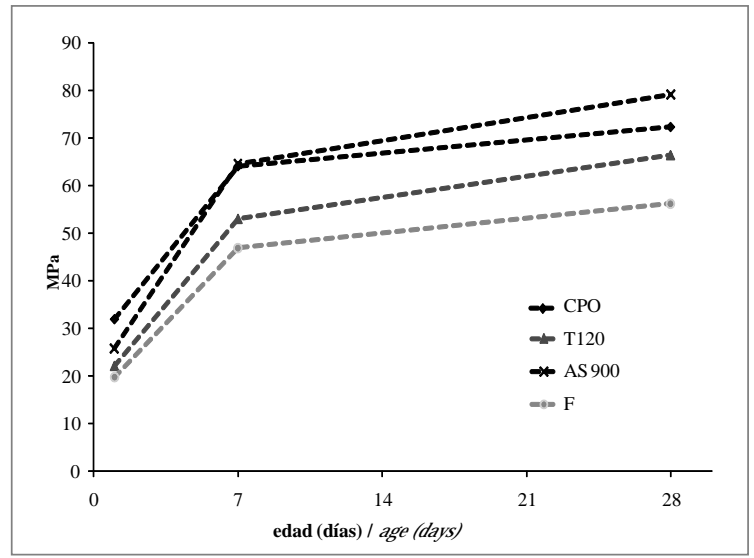

Figura 2. Resistencia a la compresión en microhormigones Figure 2. Compressive strength in micro-concretes

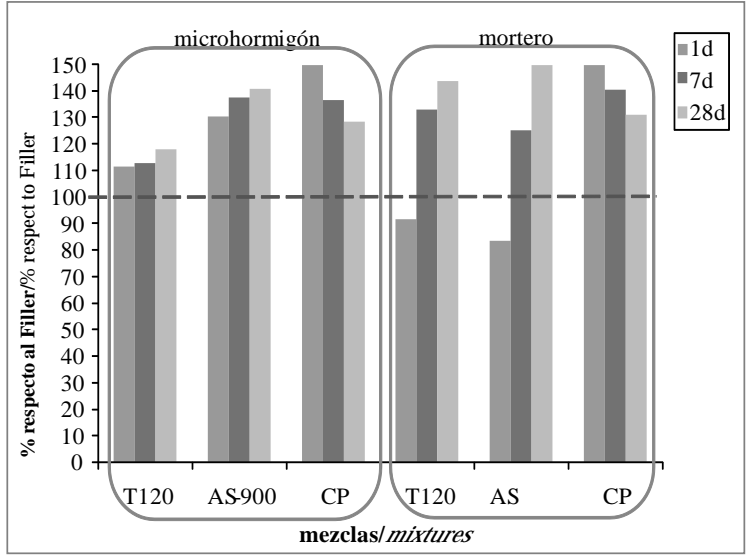

Figura 3. Comparación entre morteros y microhormigones Figure 3. Comparison between mortars and micro-concretes 


\section{Water absorption}

Changes in pores structure are determinant for concrete durability. Their formation and development throughout time was evaluated by means of a capillary water absorption test (Figure 4), which enabled the measurement of sorptivity values for each sample (Figure $6)$. In this way the contribution from active minerals admixtures was studied, as a replacement of ordinary Portland cement, on durability behavior of elaborated micro-concretes.
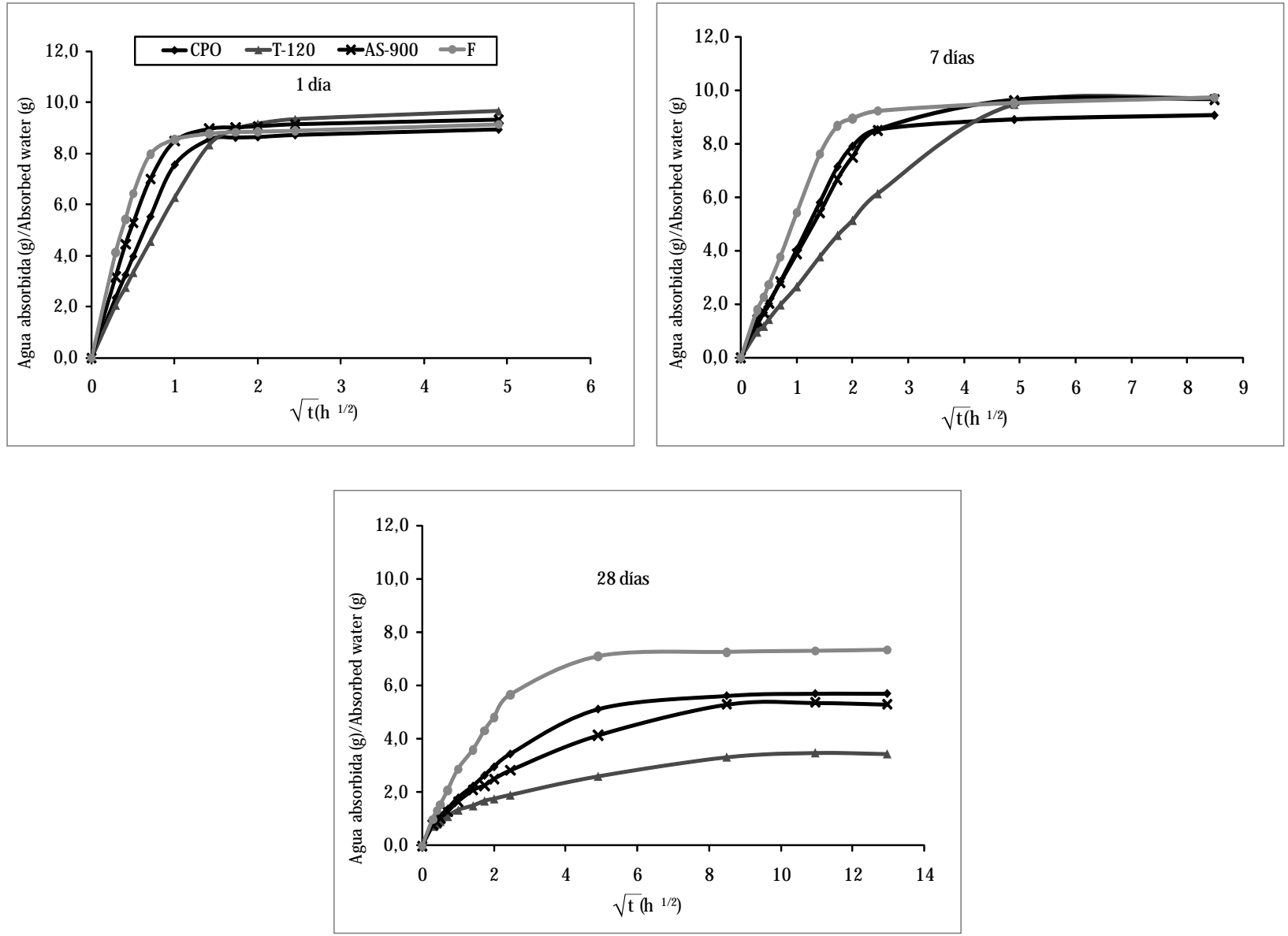

Figura 4. Absorción de agua en microhormigones

Figure 4. Water absorption in micro-concretes 
Curves in Figure 4 show a decrease of water absorption for all specimens throughout time, which suggests a micro-structure densification due to hydrates development as compaction increases and, consequently porosity deceases. This phenomenon is marked in the case of calcined clay soil (T-120), since at 28 days this is the specimen showing lower water absorption results. Admixture fineness can be fundamental for results in this sample, since a compaction or packaging effect could predominate among particles.

In curves Figure 4 it is remarkable that for all ages Filler (F) is predominant having lower time value at critical point (curve inflexion point from which there are no significant variations for water absorption values; it shall be defined as the intersection of two projection lines; from practical point of view is when water level has moved towards the upper section), i.e it is the one showing faster saturation throughout time. It may be due to lower content of reaction products, since cement was replaced by an almost inert material leading to an insufficient filling of cementious matrix. Consequently, porosity increases in comparison to the other systems hence it is the higher absorption system.

In the same figure it is remarkable that total water absorption values do not seem to vary significantly, unlike critical points in each system that displace towards the right meaning that they need longer time to achieve saturation.

Another relevant factor on material durability is effective porosity, which is water volume a concrete is able to absorb under given conditions, results are expressed in Figure 5.

Figure 5 shows that all studied materials reduced percentage of absorbed water volume throughout time, because concrete structure is denser, thus decreasing porosity. In the case of calcined clay soil T-120, it reaches the lower porosity percentage at 28 days, while AS-900 is quite similar to pure Portland cement (OPC). System elaborated from sedimentary and calcined clay AS- 900 shows a clear trend to decrease porosity at older ages, quite lower than micro-concrete sample elaborated without Portland cement replacement. 


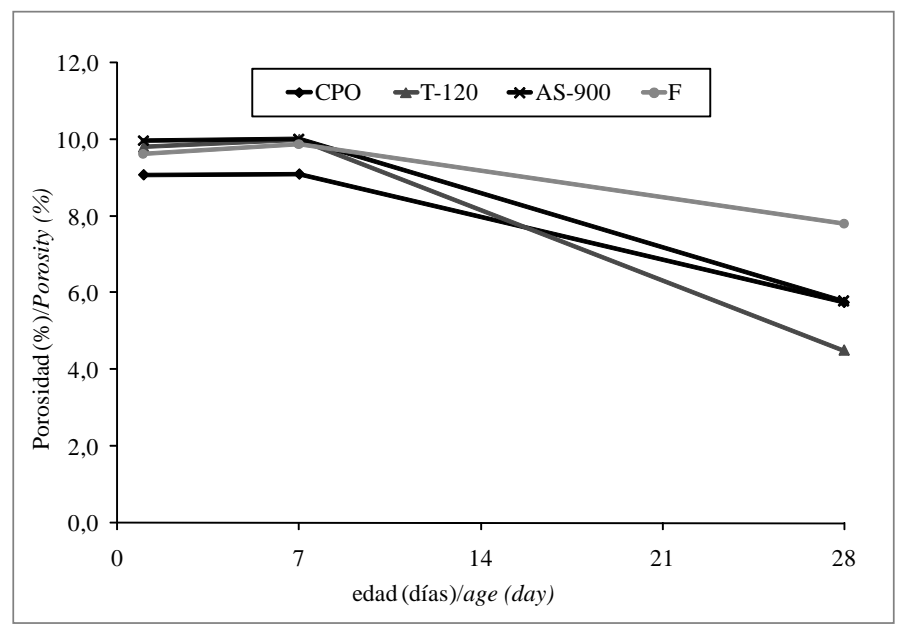

Figura 5. Porosidad efectiva

Figure 5. Effective porosity

Figure 6 shows that calcined clay soil (T-120) is once again the mineral admixture having best behavior throughout time, reaching lower sorptivity values at 28 days. At the same age, micro-concretes elaborated with $100 \%$ of Portland cement as well as those with a $30 \%$ replacement by sedimentary and calcined clay, have quite similar sorptivity values, which indicate a trend to achieve lower values for the case of AS-900 system; they could even exceed T-120 values at older ages. It means that when these types of puzzolans are used to replace Portland cement, it is possible to decrease water penetration level inside a concrete mass, thus avoiding direct and stronger effects from aggressive elements affecting material durability.

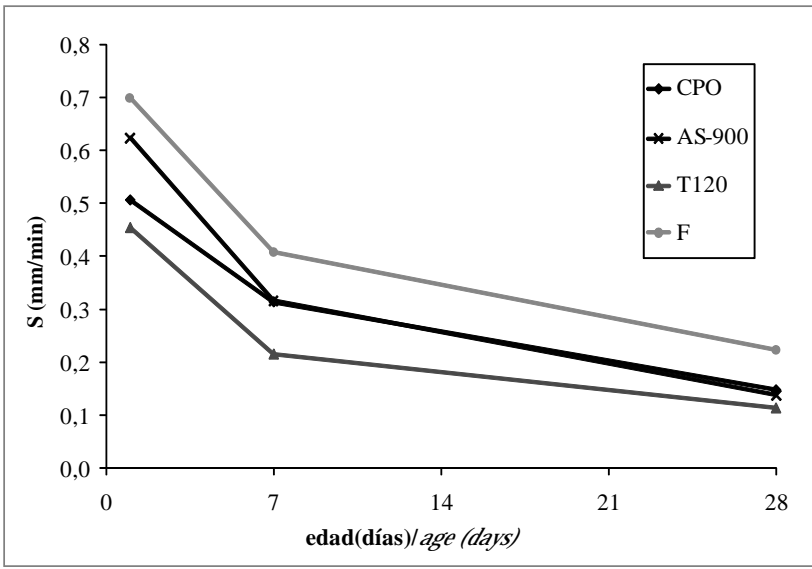

Figura 6. Sorptividad en microhormigones Figure 6. Sorptivity in Micro-concretes 
C-S-H Analysis by means of EDX

Polished sections were prepared on different micro-concrete samples to conduct EDX analysis. The main purpose was to evaluate calcined clays (AS-900) contribution on material cementious micro-structure therefore; results from sedimentary calcined clays (AS$900)$ were compared to pure Portland cement's values $(O P C)$. Figure 7 shows representative points where analyses were conducted: $\mathrm{a}$ ) internal C-S-H and b) external C-S-H.
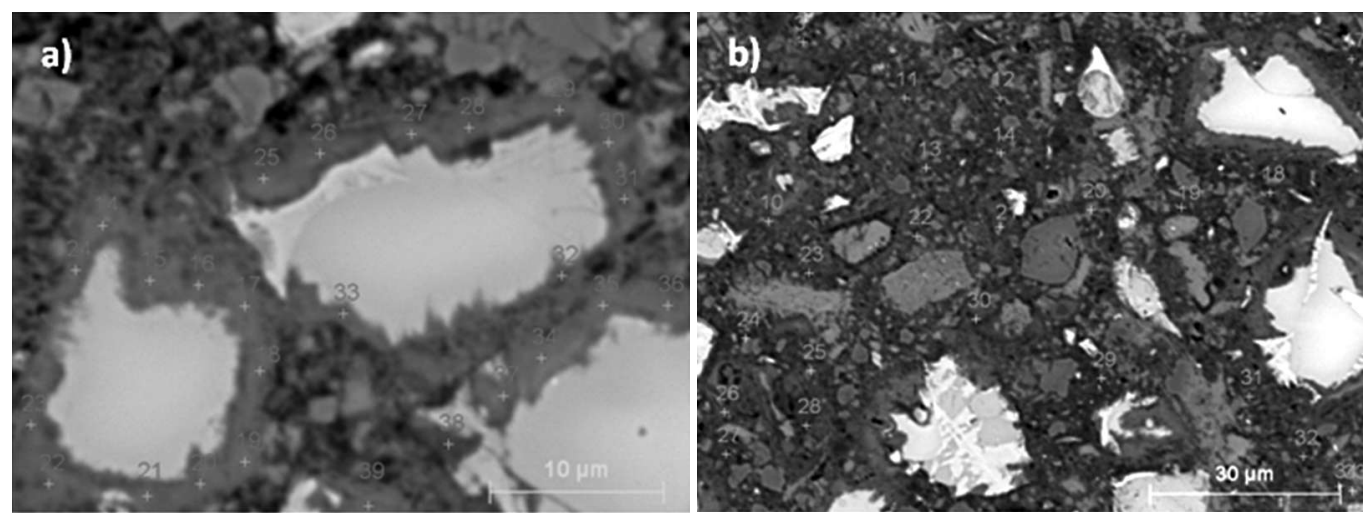

Figura 7. Ejemplo de puntos seleccionados para análisis de EDX en el a) C-S-H interno y b) C-S-H externo Figure 7. Example of selected points to analyze internal C-S-H and external C-S-H by means of EDX

Elements atomic relations found by dots analysis were plotted as $\mathrm{S} / \mathrm{Ca}$ vs. Al/Ca for variability analysis on $\mathrm{C}-\mathrm{S}-\mathrm{H}$, while S/Ca vs. Al/Ca graphs show the presence and type of et tringite phases (AFt) and monosulfos (AFm).
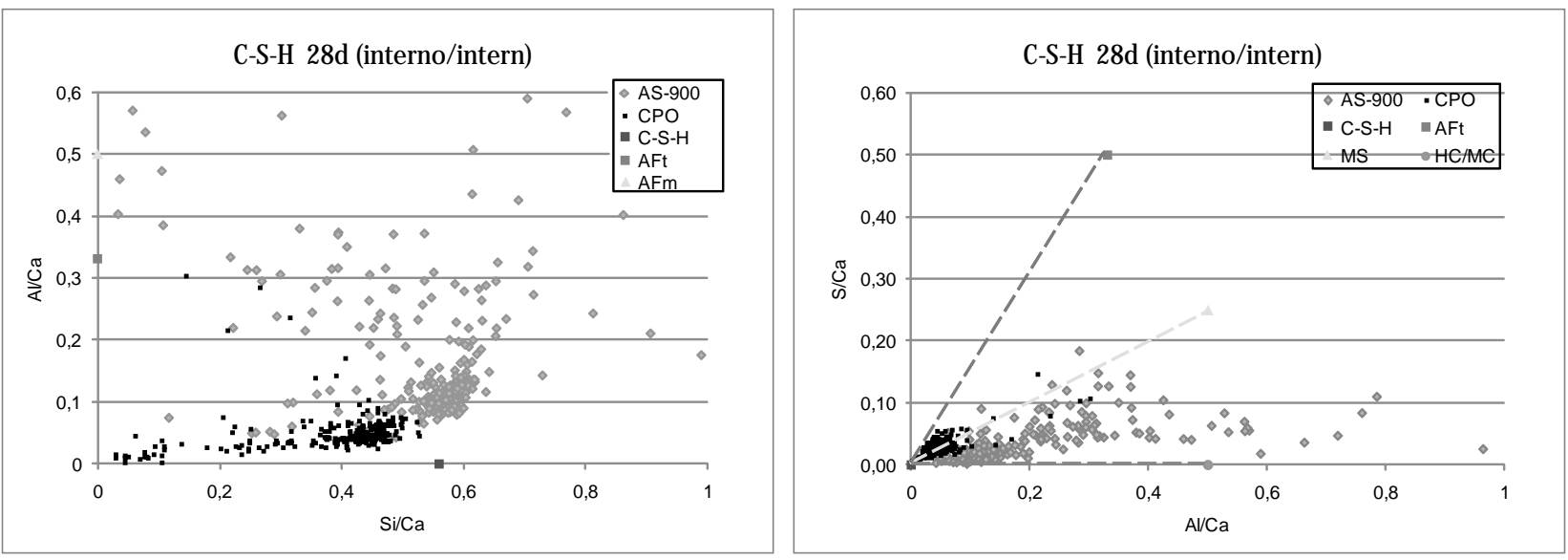

Figura 8. Análisis de EDX en C-S-H interno a los 28 días en microhormigones de AS-900 y CPO

Figura 8. EDX Analysis on internal C-S-H at 28 days for AS-900 and OPC micro-concretes 

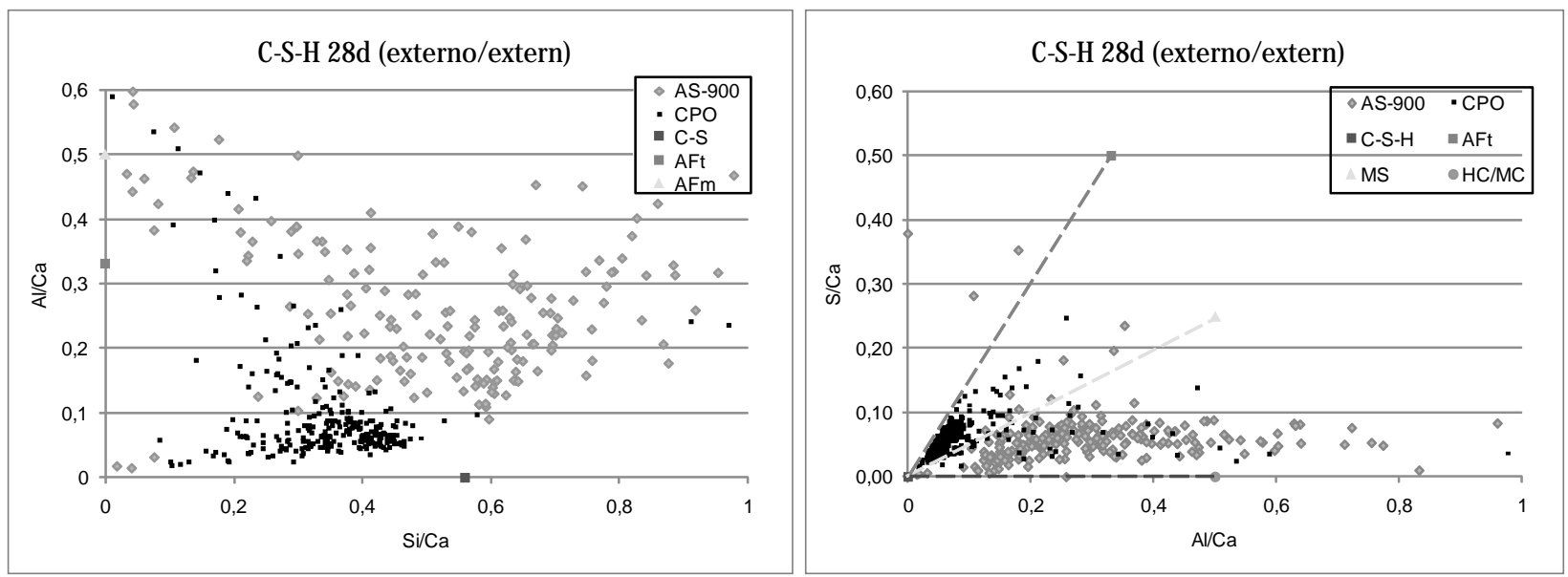

Figura 9. Análisis de EDX en C-S-H externo a los 28 días en microhormigones de AS-900 y CPO

Figure 9. EDX Analysis on external C-S-H at 28 days for AS-900 and O PC micro-concretes

Graph on the left, Figures 8 and 9, shows there is higher composition variability for external C-S-H than internal $\mathrm{C}-\mathrm{S}-\mathrm{H}$, due to the co-existence of diverse hydrate and non-hydrate phases. When electrons interaction sphere inside a sample involves more than one phase, EDX technique delivers a composition average, consequently external C-S-H has a disperser dots distribution.

On the other hand, dots for high $\mathrm{Si} / \mathrm{Ca}$ y Al/Ca reactions on external C-S-H (Figure 9, left), indicate the presence of clay particles mixed with C-S-H. Besides, it is observed that addition of calcined clay favors the formation of monosulfo (AFm) phases for internal and external C-S-H mainly hemicabo and monocarbo type ( $\mathrm{HC} / \mathrm{MC})$, in accordance to previous reference studies (Fernandez 2009). Above agrees with additional aluminum contribution developed by calcined clay reacting to calcium carbonate used as extensor in cement. Summarizing, addition of calcined clay as replacement of Portland cement favors a development of hydration process and the formation of stable products by means of such reaction.

\section{Conclusions}

The following conclusions were achieved from the analysis of obtained results: 
- Compressive strength analysis delivered best results at 28 days for micro-concrete elaborated from sedimentary and calcined clay (AS-900). At this age compressive strength increase in this admixture, due to puzzolanic reaction, was approximately $40 \%$ in relation to filler system, which behaves as a relatively inert material and contains the same amount of cement.

- The employment of active mineral admixtures on micro-concrete reduces material capillary porosity, calcined clay soil standing out with a decrease of more than $20 \%$ in relation to the pure cement reference at 28 days. Apparently, high fineness of such pozzolan affects pore internal structure enabling higher impermeability in relation to other elaborated micro-concretes.

- Micro-concretes obtained from the use of calcined clays as replacement of ordinary Portland cement, show a sorptivity decrease at 28 days in relation to pure Portland cement reference sample. Best results were obtained by calcined clay soil (T-120) due to high fineness achieved by this admixture after grinding process and due to the contribution of developed puzzolanic reaction.

- The addition of calcined clay as replacement of Portland cement favors cement hydration process, which enables the formation of stable hydration phases, such as hemicabo and monocarbo.

- The results obtained from this study, by means of capillarity water absorption micro-structural tests conducted at micro-scale energy dispersive $\mathrm{x}$-ray (EDX) analysis, demonstrate potential of clay soils to grant durability for concretes elaborated from such supplementary cementious materials, even with low purity levels. 


\section{Referencias / References}

Agarwal S. K. (2006), Pozzolanic activity of various siliceous materials, Cement and Concrete Research, 36, 1735-1739. Al-Akhras N. M. (2006), Durability of metakaolin concrete to sulfate attack, Cement and Concrete Research, 36, 1727-1734.

Bai J., et al. (2003), Chloride ingress and strength loss in concrete with different PC-PFA-MK binder compositions exposed to synthetic seawater, Cement and Concrete Research, 33, 353-362.

Castillo Lara R., et al. (2010), Activación de arcillas de bajo grado a altas temperaturas, Revista Ingeniería de Construcción, 25(3), 329-352.

Fernandez R. (2009), Calcined Clayey Soils as a Potential Replacement for Cement in Developing Countries. Ph. D., École Polytechnique Fédérale de Lausanne.

Gonçalves J. P., et al. (2009), Performance evaluation of cement mortars modified with metakaolin or ground brick, Construction and Building Materials, 23, 1971-1979.

Justice J. M. (2005), Evaluation of metakaolins for use as Supplementary Cementitious Materials. M aster of Science in Materials Science and Engineering, Georgia Institute of Technology.

Law rence P., et al. (2005), Mineral admixtures in mortars effect of type, amount and fineness of fine constituents on compressive strength, Cement and Concrete Research, 35, 1092-1105.

Mehta P. and Monteiro P. (2001), Chapter 8: Admixtures. Concrete Microstructure, Properties and Materials. M uhammed Basheer P. A. (2001), Permeation Analysis. In: Ramachandran, V. S. and Beaudoin, J. J. (eds.) Handbook of Analytical Techniques in Concrete Science and Technology. Principles, Techniques, and Applications. 685-692. O ttawa, O ntario, Canada: N oyes Publications / William Andrew Publishing, LLC N orwich, New York, U.S.A.

Papadakis V. G. and Tsimas S. (2002), Supplementary cementing materials in concrete. Part I: efficiency and design, Cement and Concrete Research, 32, 1525-1532.

Sabir B. B., et al. (2001), M etakaolin and calcined clays as pozzolans for concrete: a review, Cement and Concrete Composites, 23, 441-454.

Talero R. (2005), Performance of metakaolin and Portland cements in ettringite formation as determined by ASTM C 452-68: kinetic and morphological differences, Cement and Concrete Research, 35, 1269- 1284. 